\title{
Pengembangan media pembelajaran PPKn SD berbasis Powtoon untuk mengembangkan karakter tanggung jawab
}

\author{
${ }^{1}$ Medhitya Alda Apriliani, ${ }^{2}$ Arifin Maksum, \\ ${ }^{3}$ Prayuningtyas Angger Wardhani, ${ }^{4}$ Selvia Yuniar, 5 Setyowati

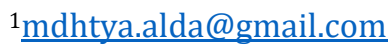 \\ 1,2,3,4Pendidikan Guru Sekolah Dasar, Fakultas Ilmu Pendidikan, Universitas Negeri Jakarta \\ ${ }^{5}$ SD Negeri Bekasi Jaya I
}

\begin{abstract}
ABSTRAK
Penelitian yang dilakukan berfokus pada pengembangan media pembelajaran video berbasis Powtoon untuk muatan pelajaran Pendidikan Pancasila dan Kewarganegaraan kelas IV sekolah dasar, khususnya materi hak dan kewajiban pada tema 2 selalu berhemat energi. Pelaksanaan penelitian ini menggunakan metode penelitian pengembangan R\&D dengan model ADDIE. Dalam model ADDIE terdapat lima tahapan, yaitu Analyze, Design, Develop, Implement, dan Evaluate. Akan tetapi, dalam penelitian ini peneliti hanya sampai tahap Develop saja karena penelitian ini bertujuan untuk mengembangkan media pembelajaran yang layak berdasarkan penilaian dari validator. Hasil validasi media pembelajaran oleh ahli media, ahli materi, dan ahli bahasa memperoleh skor 84\% yang termasuk ke dalam kategori Sangat Layak atau Sangat Baik karena persentase dari hasil validasi berada pada rentang 81-100\%. Dengan demikian, media pembelajaran video berbasis Powtoon untuk muatan pelajaran PPKn sangat layak dimanfaatkan untuk proses pembelajaran. Media pembelajaran video berbasis Powtoon ini dapat meningkatkan pemanfaatan teknologi, di sisi lain juga membuat peserta didik antusias dalam mengikuti proses pembelajaran.
\end{abstract}

Kata kunci: pengembangan, media pembelajaran, Powtoon, PPKn

\section{The development learning media PPKn SD based on Powtoon to develop the character of responsibility}

\begin{abstract}
The research conducted focused on the development of video learning media based on Powtoon for the content of Civics Education for grade IV elementary schools, especially the material on rights and obligations in theme 2: Always Saving Energy. The implementation of this research used the R\&D development research method with the ADDIE model. In the ADDIE model there are five stages, namely Analyze, Design, Develop, Implement, and Evaluate. However, in this study, the researchers only conducted to the point of Develop because this study aimed to develop appropriate learning media based on the assessment of the validator. The results of the validation of learning media by media experts, material experts, and linguists obtained a score of $84 \%$ which was included in the very eligible or very good category because the percentage of validation results was in the range of $81-100 \%$. Thus, based on video learning media Powtoon for Civics was very feasible to be used for the learning process. Based on video learning media Powtoon can increase the use of technology, and it also makes students enthusiastic in participating in the learning process.
\end{abstract}

Keywords: development, learning media, Powtoon, civics 


\section{PENDAHULUAN}

Dewasa ini, pendidikan dituntut untuk mengikuti perkembangan zaman yang ada agar dapat terciptanya suasana kelas yang sesuai dengan kebutuhan zaman. Untuk mewujudkan hal tersebut, dibutuhkan ruang kelas yang terintegrasi dengan teknologi (Göçen et al., 2020). Berdasarkan Permendikbud Nomor 81A Tahun 2013 disebutkan bahwa pengembangan Rencana Pelaksanaan Pembelajaran harus menerapkan Teknologi Informasi dan Komunikasi dalam proses pembelajaran (Kemendikbud, 2013). Penggunaan teknologi dapat diterapkan dalam proses pembelajaran karena sebagian besar sekolah sudah memfasilitasi berbagai alat yang akan mendukung penggunaan teknologi di dalam proses pembelajaran (Puspitarini et al., 2018). Pada abad 21 ini, tiap individu, termasuk pendidik dituntut untuk mendapatkan keterampilan baru agar mampu mengikuti perubahan dan kemajuan yang ada serta menyesuaikan dengan kehidupan sehari-hari (Ciğerci, 2020). Pada abad 21, pendidik dituntut harus dapat memanfaatkan kecanggihan teknologi yang tersedia. Pendidik pada abad 21, harus menguasai konten keterampilan mengajar agar dapat mengintegrasikan teknologi di dalam proses pembelajaran (Jan, 2017).

Akan tetapi, pendidik sekolah dasar tidak menampilkan pembelajaran abad ke-21. Sebagian besar pembelajaran mengadopsi pembelajaran yang berpusat pada pendidik, penggunaan metode konvensional mengakibatkan kurang berkembangnya high-order thinking (HOT) peserta didik, tidak adanya penggunaan teknologi dalam proses belajar mengajar, dan tidak menyetujui perkembangan belajar peserta didik di tingkat SD (Sumardi et al., 2020). Hal tersebut sejalan dengan temuan di lapangan, diketahui bahwa masih terdapat banyak pendidik yang belum mampu untuk mengembangkan media pembelajaran berbasis elektronik. Dalam proses pembelajaran, pendidik masih jarang menggunakan media pembelajaran, baik media pembelajaran konvensional ataupun media pembelajaran berbasis elektronik. Pendidik lebih sering menggunakan metode ceramah. Dengan tidak adanya media pembelajaran, tentunya proses pembelajaran di kelas akan terasa membosankan dan tidak menarik. Hal tersebut mengakibatkan berkurangnya antusiasme dari peserta didik dalam mengikuti proses pembelajaran. Proses pembelajaran akan menjadi lebih efektif jika terdapat penggunaan media pembelajaran di dalamnya (Yatri \& Pratiwi, 2017). Untuk meningkatkan antusiasme 
peserta didik, diperlukan media pembelajaran yang terbaru dan menarik, yaitu media pembelajaran berbasis elektronik (Anjarsari et al., 2020).

Pengembangan media pembelajaran berbasis elektronik perlu dilakukan oleh pendidik, dengan tujuan meningkatkan antusias peserta didik dalam mengikuti proses pembelajaran (Puspitarini \& Hanif, 2019). Media pembelajaran harus dapat memotivasi peserta didik agar tujuan pembelajaran dapat tercapai. Melihat situasi saat ini, media pembelajaran video berbasis Powtoon perlu untuk dikembangkan. Media pembelajaran video akan membawa dampak positif (Martens \& Gainous, 2013). Akan tetapi, media video berbasis Powtoon belum banyak digunakan (Ponza et al., 2018). Padahal media video berbasis Powtoon berpotensi tinggi dalam menarik perhatian peserta didik (Lestari et al., 2018). Media video berbasis Powtoon juga dapat mengatasi perbedaan gaya belajar peserta didik. Dengan menonton video pembelajaran peserta didik mendapat banyak stimulus, karena sifatnya suara dan gambar (Fitriyani, 2019). Selain itu, peserta didik mengungkapkan media pembelajaran video berbasis Powtoon lebih mudah untuk dipelajari, karena menarik perhatian (Poggiali, 2018).

Powtoon merupakan sebuah aplikasi atau perangkat lunak (software) yang dapat digunakan untuk membuat media pembelajaran, karena memiliki fitur animasi, yaitu animasi tulisan tangan dan animasi kartun serta Powtoon memiliki efek transisi dan pengaturan timeline (Ilahi \& Desyandri, 2018). Powtoon memiliki beberapa keuntungan umum, yaitu 1) menampilkan topik dengan menarik dan dapat membagikannya dengan orang lain, 2) menarik perhatian peserta didik, 3) peserta didik mencapai pemahaman yang lebih baik dan materi yang disampaikan lebih mudah untuk diingat, 4) mengintegrasikan berbagai jenis format dan media, meningkatkan kemampuan integrasi visual, pendengaran, dan sumber gerak, serta 5) versi dasarnya gratis untuk digunakan (Pais et al., 2017).

Media pembelajaran berbasis Powtoon dapat digunakan pada beberapa muatan pelajaran, salah satunya adalah PPKn. PPKn merupakan muatan pelajaran yang dapat membentuk karakter peserta didik. Hal tersebut sejalan dengan Permendiknas Nomor 22 Tahun 2006, disebutkan bahwa PPKn dapat memfasilitasi penanaman pendidikan karakter. Materi-materi dalam PPKn sangat praktis untuk membuat peserta didik menjadi pribadi yang baik dan bertanggungjawab. Salah satu materinya yaitu materi hak dan kewajiban warga negara. Sebelum melaksanakan hak dan kewajiban, peserta didik terlebih dahulu harus memahami mengenai materi serta cara pelaksanaan hak dan kewajiban. Nantinya materi serta cara pelaksanaan 
dari materi hak dan kewajiban itu akan diuraikan di dalam media pembelajaran yang akan dikembangkan.

Melalui materi hak dan kewajiban dapat dikembangkan karakter tanggung jawab. Karakter tanggung jawab merupakan karakter yang wajib terdapat pada diri tiap peserta didik. Akan tetapi, bukti empiris menunjukkan terdapat beberapa kasus yang membuktikan rendahnya karakter tanggung jawab, seperti peserta didik yang terlambat datang ke sekolah, membuang sampah tidak pada tempatnya, serta pekerjaan rumahnya tidak dikerjakan (Sari \& Syamsi, 2015). Perilaku yang menyimpang tersebut terjadi karena kurangnya tanggung jawab terhadap diri sendiri (Yuliyanto et al., 2018). Oleh karena itu, penanaman karakter tanggung sangat perlu untuk dilakukan. Penanaman karakter tersebut dapat diwujudkan melalui kegiatan belajar mengajar dan kegiatan kehidupan sehari-hari di sekolah (Ash-shidiqqi, 2018). Karakter yang baik sangat penting bagi tiap individu karena akan mempengaruhi perilakunya dalam kehidupan pribadi, sosial, dan negara (Septiani et al., 2020).

Beberapa penelitian terdahulu mengenai pengembangan media pembelajaran video berbasis Powtoon juga memperlihatkan hasil yang positif. Pada penelitian (Ponza et al., 2018), yang melakukan penelitian terkait pengembangan media pembelajaran video berbasis Powtoon dalam pembelajaran tematik didapatkan hasil bahwa media tersebut efektif meningkatkan hasil belajar peserta didik. Media yang dikembangkan berkualitas "Sangat Baik" dan dinyatakan valid. Hal tersebut ditunjukkan oleh perbedaan hasil belajar peserta didik yang signifikan antara sebelum dan sesudah menggunakan video pembelajaran berbasis Powtoon. Pada penelitian (Nurdiansyah et al., 2018), yang melakukan pengembangan video pembelajaran berbasis Powtoon pada perkuliahan Pendidikan Kewarganegaraan di Universitas Sriwijaya juga dinyatakan valid sesuai pendapat dari para ahli, dan praktis dalam penerapannya, serta berefek potensial dalam meningkatkan pemahaman mahasiswa terhadap materi perkuliahan. Begitu pun dalam penelitian (Ardiansyah et al., 2019), yang melakukan pengembangan media pembelajaran video berbasis Powtoon dalam muatan pelajaran PPKn untuk pengenalan suku dan budaya Indonesia mendapat kategori sangat positif. Respon peserta didik terhadap media pembelajaran pengenalan suku budaya Indonesia mendapatkan respon yang baik, mereka sangat tertarik dan antusias untuk melihat dan mempelajari suku budaya dengan cara menonton video animasi yang ditampilkan. Berbeda pada penelitian-penelitian terdahulu, penelitian ini berfokus pada pengembangan media 
pembelajaran video berbasis Powtoon dalam muatan pelajaran PPKn untuk mengembangkan karakter tanggung jawab pada materi hak dan kewajiban kelas IV.

Penelitian pengembangan media pembelajaran video berbasis Powtoon untuk muatan pelajaran PPKn ini relevan dengan penelitian yang dilakukan oleh Nuswantoro \& Wicaksono pada tahun 2019. Dalam penelitian tersebut dinyatakan bahwa media pembelajaran video berbasis Powtoon HAKAN memenuhi kriteria kelayakan. Perbedaan dengan pengembangan ini, yaitu 1) Bersumber pada buku peserta didik tema 2 Selalu Berhemat Energi, sedangkan penelitian sebelumnya bersumber pada buku peserta didik tema 9 Kayanya Negeriku dan 2) Menggunakan model ADDIE, sedangkan penelitian sebelumnya menggunakan model PLOOMP.

Berdasarkan pemaparan yang telah dikemukakan, rumusan masalah dalam penelitian ini adalah Bagaimana pengembangan media pembelajaran video berbasis Powtoon untuk mengembangkan karakter tanggung jawab pada muatan pelajaran PPKn materi hak dan kewajiban tema 2 selalu berhemat energi kelas IV.

\section{METODE PENELITIAN}

Dalam pelaksanaan penelitian ini digunakan metode penelitian pengembangan R\&D (Research and Development). Metode penelitian pengembangan R\&D merupakan metode yang dapat digunakan untuk menghasilkan suatu produk tertentu (Sugiono, 2012). Dapat pula dikatakan bahwa metode penelitian pengembangan $\mathrm{R} \& \mathrm{D}$ adalah rangkaian beberapa tahapan dalam rangka menghasilkan suatu produk, baik produk baru ataupun menyempurnakan produk yang sudah ada agar dapat dipertanggungjawabkan (Salim \& Haidir, 2019). Produk yang dihasilkan dapat berbentuk perangkat keras (hardware) maupun perangkat lunak (software). Metode penelitian pengembangan R\&D ini dipilih dikarenakan peneliti akan menghasilkan suatu produk berbentuk perangkat lunak (software).

Model pengembangan ADDIE dipilih untuk menghasilkan suatu produk berbentuk perangkat lunak (software). Dipilihnya model pengembangan ADDIE dikarenakan dapat mengembangkan produk dengan efektif dan efisien, sehingga nantinya produk yang dihasilkan dapat dengan layak untuk digunakan (Lestari et al., 2018). Tahapan penelitian merupakan langkah yang dilakukan berdasarkan model yang telah dipilih. Tahap-tahap kegiatan model ADDIE memiliki kaitan satu sama lain (Pribadi, 2016). Dalam pelaksanaan penelitian ini, peneliti menggunakan tahap Analyze, Design, dan Develop. Untuk tahap Implement dan Evaluate tidak digunakan dikarenakan terpatok pada waktu. 
Pertama adalah tahap Analyze, tahap analisis merupakan langkah awal atau dasar dalam proses pengembangan media pembelajaran. Analisis dilakukan untuk mendapatkan informasi terkait kebutuhan yang harus dipenuhi. Dalam tahap ini, dilakukan studi literatur dan penelitian pra lapangan berupa analisis kebutuhan. Analisis kebutuhan dilakukan dengan cara menyebarkan angket kepada pendidik dan peserta didik kelas IV melalui Google Forms. Analisis dilakukan terhadap tingkat kebutuhan di lapangan terkait media pembelajaran untuk muatan pelajaran PPKn, khususnya kelas IV. Hasil analisis kebutuhan tersebut menjadi acuan utama dalam mengembangkan media pembelajaran video berbasis Powtoon. Hasil dari analisis kebutuhan tersebut dipadukan dengan hasil kajian dari studi literatur. Selain itu, peneliti melakukan analisis materi yang sesuai dengan Kurikulum 2013. Analisis materi dilakukan untuk menentukan materi pembelajaran mana yang akan dikembangkan. Peneliti melakukan analisis materi dengan mengkaji buku tema 1-9 kelas IV. Kemudian, juga dilakukan analisis perangkat untuk mengetahui peralatan yang akan digunakan dalam mengembangkan media pembelajaran, baik software maupun hardware. Hasil dari tahap analisis ini menjadi masukan untuk tahap selanjutnya.

Kedua adalah tahap Design, tahap perancangan bertujuan untuk membuat desain awal dari media pembelajaran yang akan dikembangkan. Pada tahap ini dilakukan pemindahan informasi yang diperoleh pada tahap analisis ke dalam bentuk dokumen. Peneliti merancang media pembelajaran dengan bantuan aplikasi Microsoft Word. Media pembelajaran yang dirancang berisikan materi hak dan kewajiban terhadap energi, yang dilengkapi juga dengan gambar. Peneliti juga memilih efek suara atau sound effect yang nantinya akan dimasukkan ke dalam media setelah dilakukan proses pengembangan media. Penggunaan efek suara atau sound effect ini bertujuan untuk menambah nilai ketertarikkan peserta didik. Peneliti juga menentukan animasi yang akan digunakan. Bahasa yang digunakan jelas, lugas, dan konsisten agar peserta didik dapat dengan mudah mengerti dan memahami materi yang disampaikan sehingga tujuan pembelajaran dapat tercapai dengan baik. Dalam media pembelajaran terdapat ajakan agar peserta didik selalu melaksanakan hak dan kewajiban terhadap energi. Media pembelajaran yang akan dikembangkan bertujuan untuk memudahkan pendidik dalam menyajikan materi. Selain itu, juga bertujuan untuk membantu meningkatkan antusiasme peserta didik dalam mengikuti proses pembelajaran dan memudahkan peserta didik dalam menyerap materi yang diajarkan. 
Ketiga adalah tahap Develop, tahap pengembangan merupakan tahap mengubah kerangka yang masih konseptual menjadi produk yang utuh dan siap untuk digunakan. Pengembangan dimulai dengan membuat gambar dengan bantuan aplikasi Canva. Kemudian, dilakukan pengubahan teks materi menjadi audio dengan bantuan aplikasi T2S. Setelah itu, dilakukan pembuatan media pembelajaran video dengan menggunakan aplikasi Powtoon. Powtoon digunakan karena aksesnya cukup mudah dengan hanya menggunakan internet. Dalam pengembangan, digunakan beragam fitur yang terdapat pada aplikasi Powtoon, seperti scenes, text, character, props, serta shapes. Pada aplikasi Powtoon peneliti memasukan teks dan gambar. Pemunculan dari teks dan gambar diatur dengan timeline. Selain itu, peneliti menggunakan karakter animasi. Karakter animasi yang dipilih berupa karakter anak kecil dan karakter orang dewasa. Setelah media pembelajaran selesai dibuat, kemudian di-export menggunakan YouTube untuk mendapatkan video dengan format MP4, dikarenakan video Powtoon yang telah dibuat hanya akan tersimpan pada laman Powtoon. Setelah mendapatkan video dengan format MP4, peneliti memasukkan suara atau dubbing yang disesuaikan dengan pemunculan teks dan gambar dengan bantuan aplikasi VN. Pada aplikasi VN, peneliti juga menambahkan efek suara atau sound effect. Terdapat beberapa revisi dari validator agar media pembelajaran layak dan dapat digunakan untuk mendukung proses pembelajaran. Kemudian, peneliti memperbaiki berdasarkan pertimbangan dari data, saran, dan masukan yang terdapat pada instrumen angket penilaian yang diberikan oleh validator.

Pengembangan media pembelajaran video berbasis Powtoon ini, dikemas secara menarik dengan tujuan meningkatkan daya tarik peserta didik. Di dalam video dikombinasikan tulisan, gambar, suara, efek suara, serta animasi. Video pembelajaran ini dapat digunakan oleh peserta didik kapanpun dan dimanapun peserta didik itu berada karena video pembelajaran ini diunggah di YouTube.

Dalam penelitian ini digunakan teknik angket untuk mengumpulkan data. Angket yang digunakan untuk mengumpulkan data yaitu angket validasi ahli. Angket tersebut bertujuan untuk memberikan penilaian serta mengetahui kualitas media pembelajaran yang dihasilkan. Dalam penelitian ini, digunakan analisis desktiptif untuk menganalisis data. Selain itu, digunakan rumus pengukuran skala likert guna memperoleh persentase skor penilaian dari validator.

Rentang kategori kelayakan media pembelajaran dari skala likert adalah seperti berikut. 
Tabel 1. Kategori Kelayakkan Media Pembelajaran

\begin{tabular}{ccc}
\hline No & Tingkat Pencapaian & Kategori \\
\hline 1 & $0 \%-20 \%$ & Sangat Tidak Layak \\
2 & $21 \%-40 \%$ & Tidak Layak \\
3 & $41 \%-60 \%$ & Cukup Layak \\
4 & $61 \%-80 \%$ & Layak \\
5 & $81 \%-100 \%$ & Sangat Layak \\
\hline
\end{tabular}

Media pembelajaran dinyatakan layak apabila memperoleh penilaian angket sebesar lebih dari 61\% sampai dengan $100 \%$.

\section{HASIL DAN PEMBAHASAN}

\section{Hasil Penelitian}

Pelaksanaan penelitian ini bertujuan untuk mengembangkan sebuah produk berbentuk perangkat lunak (software). Produk yang akan dihasilkan adalah media pembelajaran video berbasis Powtoon untuk muatan pelajaran PPKn materi hak dan kewajiban tema 2 selalu berhemat energi kelas IV. Untuk menghasilkan produk tersebut digunakan model pengembangan ADDIE.

Berdasarkan analisis kebutuhan, didapatkan permasalahan bahwa penggunaan media pembelajaran untuk muatan pelajaran PPKn belum terlaksana secara maksimal. Pendidik hanya menggunakan metode ceramah ketika menyampaikan materi, dan hal tersebut dirasa kurang efektif. Selain itu, pendidik sangat jarang menggunakan media pembelajaran dalam bentuk video. Padahal peserta didik menyukai proses pembelajaran yang menggunakan media pembelajaran dalam bentuk video, yang menguraikan materi dan disertai dengan contohnya secara mendetail. Berdasarkan hal tersebut, maka sangat perlu untuk dihasilkan media pembelajaran video berbasis Powtoon pada muatan pelajaran PPKn.

Dalam pengembangan media pembelajaran diperlukan kerangka desain dengan tujuan untuk memudahkan peneliti ketika mengembangkan produk. Adapun desain dari media pembelajaran yang dibuat yaitu seperti berikut ini. 


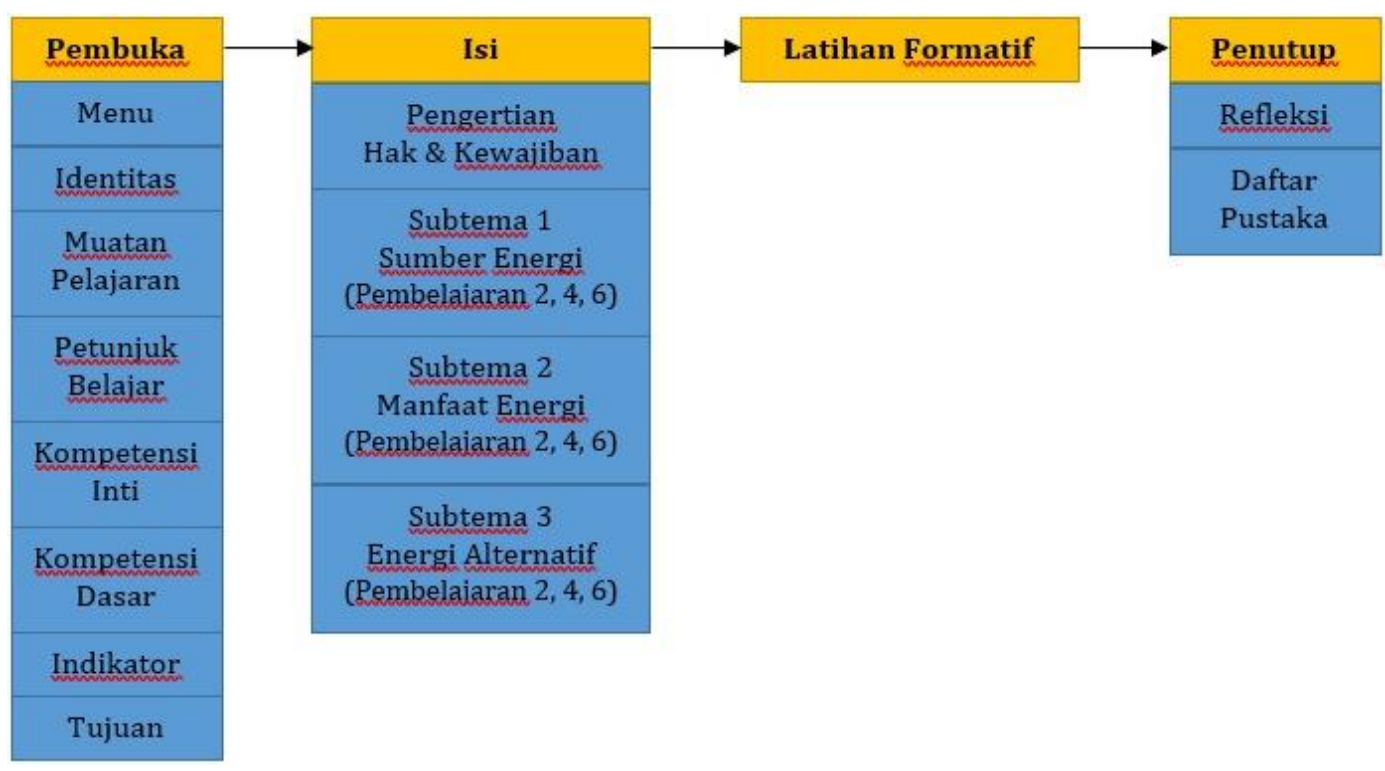

\section{Gambar 1. Kerangka Media Pembelajaran}

Produk yang telah dikembangkan sudah divalidasi oleh validator. Uji validasi dilakukan oleh ahli media, ahli materi, dan ahli bahasa. Uji validasi ini bertujuan untuk mendapatkan informasi berupa masukan secara keseluruhan dari para ahli terhadap media pembelajaran yang dikembangkan, baik dari desainnya, materinya, serta bahasanya. Selain itu, dilakukannya uji validasi ini juga bertujuan untuk mengetahui tingkat kelayakkan dari media pembelajaran.

Validator ahli media adalah Bapak Rossi Iskandar, M.Pd. selaku dosen PGSD Universitas Trilogi, Jakarta. Berikut hasil rekapitulasi dari ahli media.

Tabel 2. Hasil Rekapitulasi Ahli Media

\begin{tabular}{|c|c|c|c|}
\hline No & Indikator & Item Soal & Skor \\
\hline 1 & Kriteria Pendidikan & 5 & 23 \\
\hline 2 & Tampilan Program & 10 & 43 \\
\hline 3 & Kualitas Teknis & 5 & 21 \\
\hline & Jumlah & 20 & $87 \%$ \\
\hline & Kategori & \multicolumn{2}{|c|}{ Sangat Layak } \\
\hline
\end{tabular}

Berdasarkan Tabel 2. Hasil Rekapitulasi Ahli Media terdapat tiga indikator penilaian ahli media, yaitu kriteria pendidikan yang memperoleh skor 23, tampilan program yang memperoleh skor 43, dan kualitas teknis yang memperoleh skor 21 . Ketiga indikator tersebut menghasilkan skor 87\% sehingga didapatkan kategori Sangat Layak. Validator ahli media memberikan saran serta masukan. Hasil 
perbaikan dari saran yang diberikan oleh validator ahli media adalah sebagai berikut.

Tabel 3. Revisi Media Pembelajaran dari Validasi Ahli Media

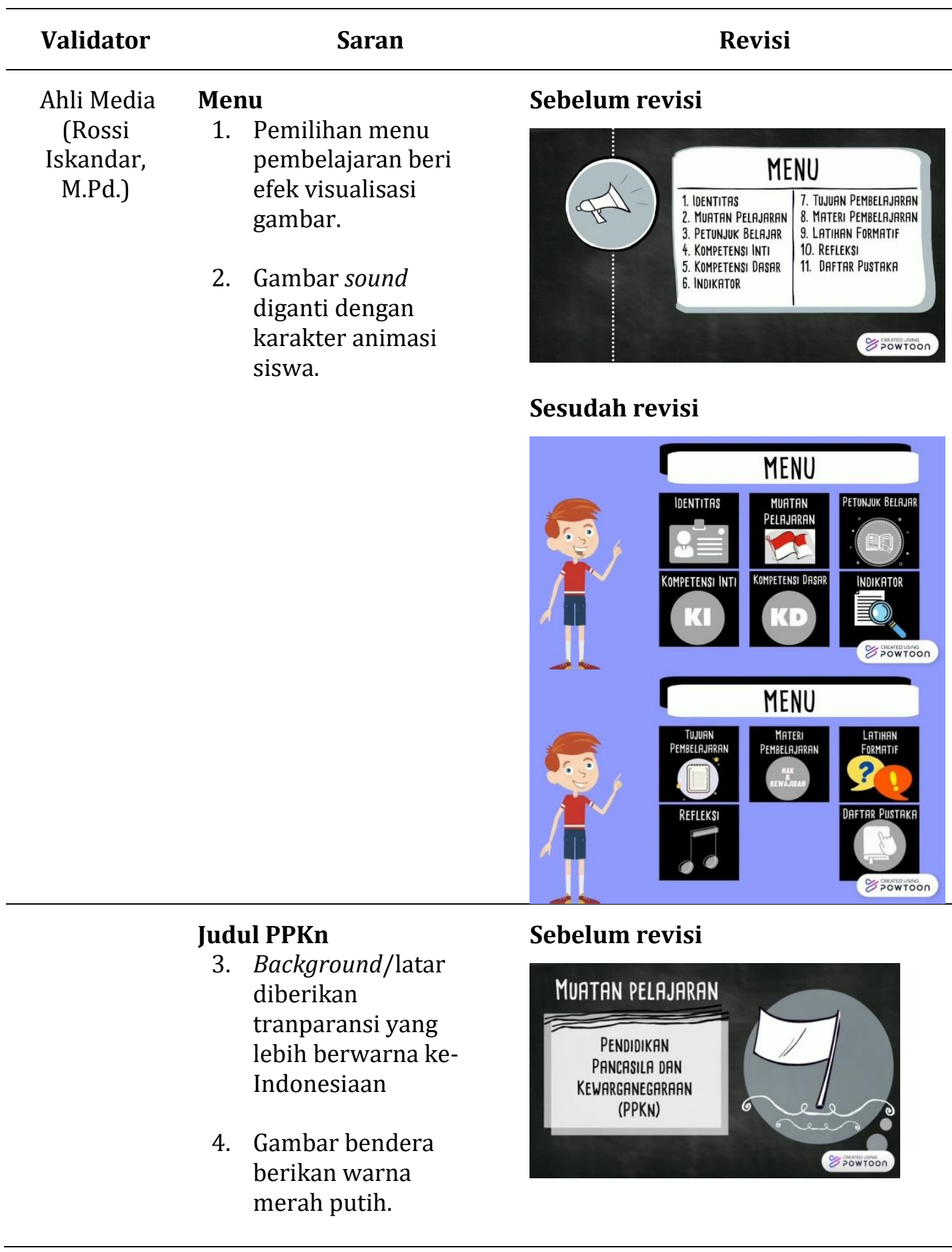




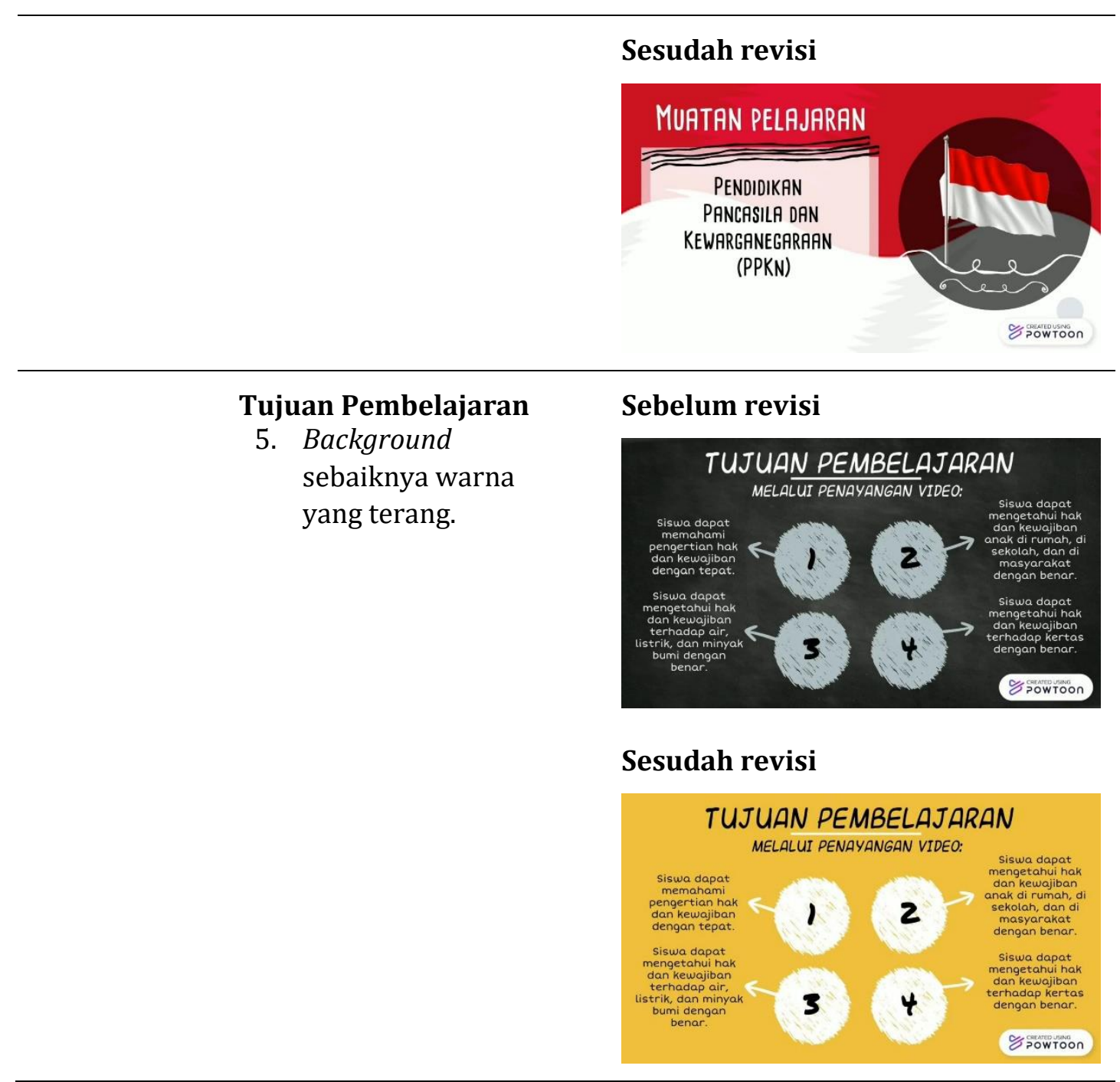

Validator ahli materi adalah Bapak Dudu Suhandi Saputra, M.Pd. selaku dosen PGSD Universitas Majalengka. Berikut hasil rekapitulasi dari ahli materi.

Tabel 4. Hasil Rekapitulasi Ahli Materi

\begin{tabular}{|c|c|c|c|}
\hline No & Indikator & Item Soal & Skor \\
\hline 1 & Relevansi Materi & 5 & 44 \\
\hline 2 & Kualitas Materi & 3 & 24 \\
\hline 3 & Kemanfaatan Materi & 2 & 16 \\
\hline & Jumlah & 10 & $84 \%$ \\
\hline & Kategori & \multicolumn{2}{|c|}{ Sangat Layak } \\
\hline
\end{tabular}

Berdasarkan tabel 4, terdapat tiga indikator penilaian ahli materi, yaitu relevansi materi yang memperoleh skor 44, kualitas materi yang memperoleh skor 24, dan kemanfaatan materi yang memperoleh skor 16. Ketiga indikator tersebut menghasilkan skor 84\% sehingga didapatkan kategori Sangat Layak. Validator ahli 
materi memberikan saran dan masukan. Hasil perbaikan dari saran yang diberikan oleh validator ahli materi adalah sebagai berikut.

Tabel 5. Revisi Media Pembelajaran dari Validasi Ahli Materi

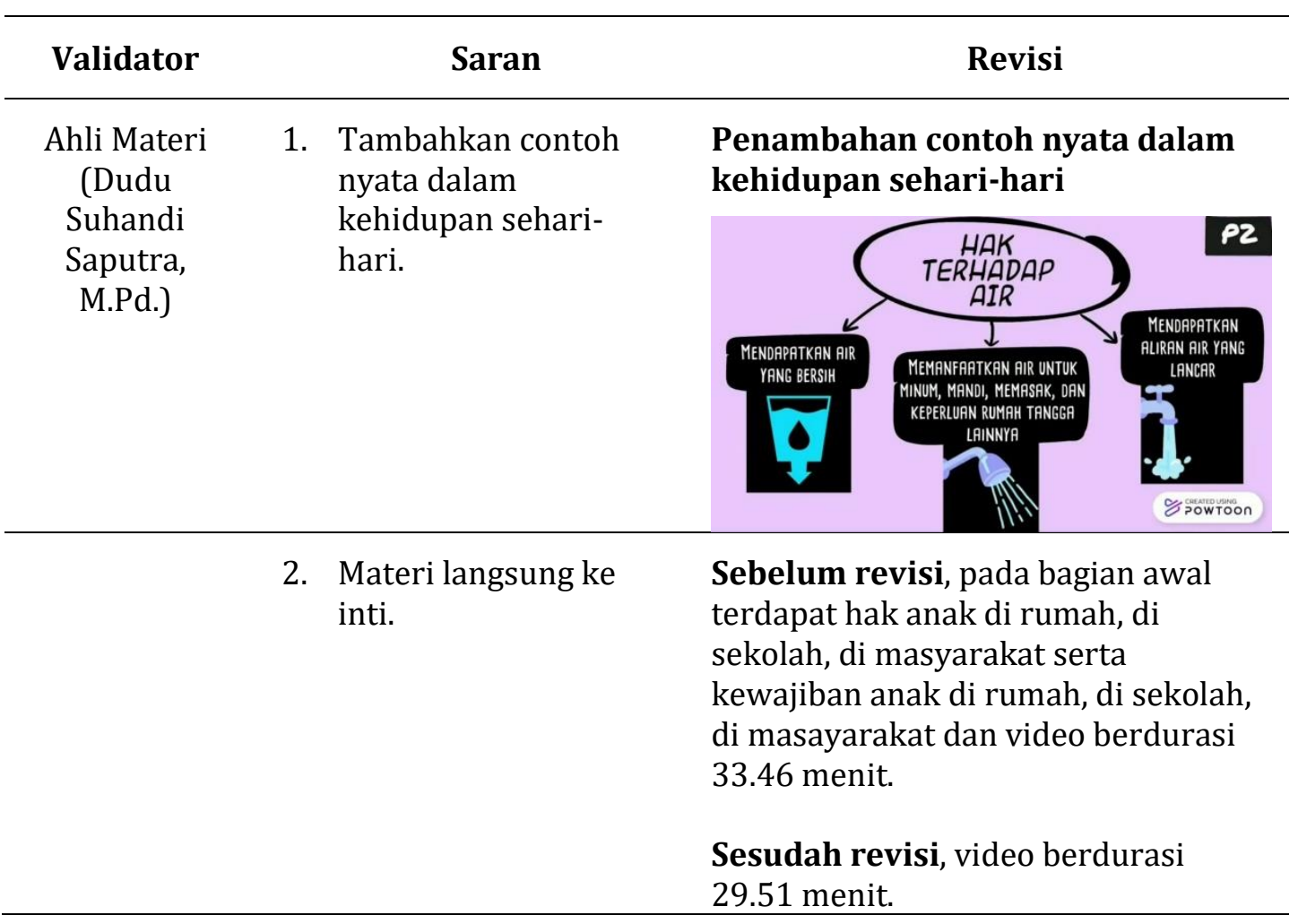

Validator ahli bahasa adalah Bapak Dudu Suhandi Saputra, M.Pd. selaku dosen PGSD Universitas Majalengka. Berikut hasil rekapitulasi dari ahli bahasa.

Tabel 6. Hasil Rekapitulasi Ahli Bahasa

\begin{tabular}{clccc}
\hline No & & Indikator & Item Soal & Skor \\
\hline 1 & \multicolumn{2}{c}{ Kualitas Bahasa } & 7 & 54 \\
2 & Tipografi & Jumlah & 3 & 28 \\
\hline \multicolumn{2}{r}{} & Kategori & 10 & $\mathbf{8 2 \%}$ \\
\hline \multicolumn{2}{r}{} & \multicolumn{2}{c}{ Sangat Layak } \\
\hline
\end{tabular}

Berdasarkan tabel 6, terdapat dua indikator penilaian ahli bahasa, yaitu kualitas bahasa yang memperoleh skor 54 dan tipografi yang memperoleh skor 28 . Kedua indikator tersebut menghasilkan skor 82\% sehingga didapatkan kategori Sangat Layak. Validator ahli bahasa memberikan saran dan masukan. Hasil perbaikan dari saran yang diberikan oleh validator ahli bahasa adalah sebagai berikut. 
Tabel 7. Revisi Media Pembelajaran dari Validasi Ahli Bahasa

\begin{tabular}{|c|c|c|}
\hline Validator & Saran & Revisi \\
\hline $\begin{array}{c}\text { Ahli Bahasa } \\
\text { (Dudu } \\
\text { Suhandi } \\
\text { Saputra, } \\
\text { M.Pd.) }\end{array}$ & $\begin{array}{l}\text { 1. Bahasa pengantar } \\
\text { harus lebih } \\
\text { interaktif. }\end{array}$ & $\begin{array}{l}\text { Sebelum revisi, pada pembukaan } \\
\text { peneliti hanya menyebutkan nama } \\
\text { saja. } \\
\text { Sesudah revisi, peneliti } \\
\text { menyebutkan nama dan hal yang akan } \\
\text { dilakukan. }\end{array}$ \\
\hline & $\begin{array}{l}\text { 2. Tambahkan animasi } \\
\text { pada bagian yang } \\
\text { hanya terdapat } \\
\text { tulisan saja. }\end{array}$ & 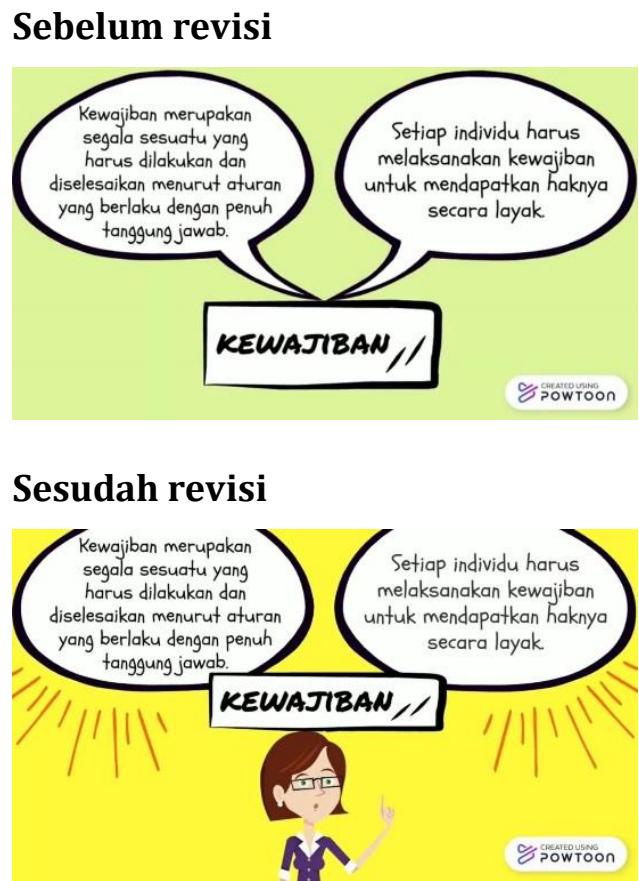 \\
\hline
\end{tabular}

Maka dapat diperoleh skor rata-rata penilaian dari validator adalah $84 \%$. Media pembelajaran video berbasis Powtoon yang dikembangkan mendapat skor $\geq 81 \%$, maka media dianggap Sangat Layak atau Sangat Baik karena perolehan skor berada pada rentang $81 \%-100 \%$. Melalui hasil penilaian dari validator didapatkan kesimpulan bahwa produk berupa media pembelajaran video berbasis Powtoon layak untuk digunakan.

Media pembelajaran video berbasis Powtoon ini dibagi menjadi empat bagian, yaitu pembuka, isi, latihan formatif, serta penutup dan dapat digunakan untuk muatan pelajaran PPKn kelas IV pada tema 2 Selalu Berhemat Energi subtema 1 (Sumber Energi), 2 (Manfaat Energi), dan 3 (Energi Alternatif). Media 
pembelajaran video berbasis Powtoon ini menggabungkan tulisan atau teks, gambar, suara atau dubbing, efek suara atau sound effect, serta animasi dalam satu kesatuan. Dalam media pembelajaran diberikan aspek pendidikan karakter, khususnya karakter tanggung jawab. Media pembelajaran ini berdurasi \pm 30 menit. Media pembelajaran ini diunggah di YouTube, dengan tujuan agar mudah diakses dan dapat digunakan berkali-kali oleh pendidik ataupun peserta didik yang membutuhkan materi tersebut.

\section{Pembahasan}

Dalam proses pembelajaran, media pembelajaran merupakan salah satu komponen pembelajaran yang tidak dapat terpisahkan. Terdapat berbagai macam jenis media pembelajaran yang dapat digunakan dalam proses pembelajaran, salah satunya adalah media pembelajaran video berbasis Powtoon. Berdasarkan hasil dari penelitian di atas, media pembelajaran video berbasis Powtoon sangat layak untuk digunakan dalam proses pembelajaran. Selain itu, media pembelajaran video berbasis Powtoon dapat digunakan karena dapat menampilkan beragam fitur animasi, seperti animasi tulisan tangan dan animasi kartun. Hal tersebut dapat menjadikan media pembelajaran yang dikembangkan dengan menggunakan Powtoon akan terkesan lucu serta menarik, yang tentunya sangat cocok untuk peserta didik sekolah dasar. Selain itu, media pembelajaran yang menggunakan animasi lebih efektif daripada media pembelajaran secara tradisional (Aksoy, 2012). Media pembelajaran yang menggunakan animasi juga dapat membuat materi pembelajaran menjadi lebih mudah untuk diterima dan dipahami oleh peserta didik (Sukiyasa \& Sukoco, 2013).

Media pembelajaran video berbasis Powtoon sangat sesuai dengan tuntutan dari Kurikulum 2013. Kurikulum 2013 mewajibkan diterapkannya Teknologi Informasi dan Komunikasi dalam proses pembelajaran. Selain itu, pembaharuan di dalam bidang pendidikan memang perlu untuk dilakukan dengan tujuan meningkatkan kualitas pendidikan. Terintegrasinya internet dalam proses pembelajaran dapat meningkatkan kualitas pendidikan (Sukmayadi \& Yahya, 2020). Proses pembelajaran juga akan menjadi lebih efektif dan interaktif jika mengikuti perkembangan teknologi yang ada.

Media pembelajaran video berbasis Powtoon yang dikembangkan ini juga dapat dijadikan media pendidikan karakter, khususnya karakter tanggung jawab. Terdapat contoh-contoh nyata di dalam media pembelajaran mengenai hak dan 
kewajiban terhadap energi. Contoh nyata tersebut dapat diterapkan peserta didik di kehidupan sehari-hari. Selain itu, di dalam media pembelajaran juga terdapat ajakan untuk selalu melaksanakan kewajiban. Proses pembelajaran dengan menggunakan media pembelajaran berbasis Powtoon ini dapat melibatkan pengalaman emosional peserta didik sehingga diharapkan akan terinternalisasi dalam afeksi serta psikomotor peserta didik yang merupakan bagian dari kepribadian peserta didik. Dengan demikian, karakter tanggung jawab yang selalu didorong dengan media pembelajaran ini diharapkan dapat membentuk karakter tanggung jawab pada diri peserta didik.

\section{SIMPULAN}

Media pembelajaran PPKn SD berbasis Powtoon yang dikembangkan sangat layak untuk diaplikasikan dalam proses pembelajaran. Kelayakan media pembelajaran tersebut ditunjukkan dengan hasil penilaian yang diberikan oleh validator. Media pembelajaran yang telah dikembangkan dapat digunakan sebagai media pembelajaran alternatif dalam meningkatkan karakter tanggung jawab peserta didik kelas IV sekolah dasar. Penggunaan media pembelajaran berbentuk video berbasis Powtoon ini sangat berpengaruh dan efektif dalam menanamkan karakter tanggung jawab peserta didik. Oleh karena itu, pendidik dapat mengoptimalkan penggunaan media pembelajaran berbasis Powtoon dalam proses pembelajaran, khususnya pada muatan pelajaran PPKn.

\section{UCAPAN TERIMA KASIH}

Dalam pembuatan artikel ini, peneliti mendapat bantuan dan dukungan dari berbagai pihak. Oleh karena itu, pada kesempatan kali ini peneliti ingin mengucapkan terima kasih yang sebesar-besarnya kepada: pendidik dan peserta didik kelas IV yang telah menyediakan waktu dan tenaganya untuk mengisi angket analisis kebutuhan; validator ahli media, ahli materi, dan ahli bahasa yang telah menyediakan waktu dan tenaganya untuk mengisi angket validasi ahli; serta semua pihak yang tidak bisa disebutkan satu per satu yang telah membantu dalam penyelesaian artikel ini.

\section{DAFTAR PUSTAKA}

Aksoy, G. (2012). The effects of animation technique on the 7th grade science and technology course. Creative Education, 3(3), 304-308. https://doi.org/10.4236/ce.2012.33048 
Anjarsari, E., Farisdianto, D. D., \& Asadullah, A. W. (2020). Pengembangan media audiovisual Powtoon pada pembelajaran Matematika untuk siswa sekolah dasar. Jurnal Matematika Dan Pendidikan Matematika, 5(2), 40-50.

Ardiansyah, H., Sindu, I. G. P., \& Putrama, I. M. (2019). Pengembangan video pembelajaran PPKn untuk pengenalan suku dan budaya Indonesia (Studi kasus: Kelas IV Madrasah Ibtidaiyah Negeri Singaraja). Kumpulan Artikel Mahasiswa Pendidikan Teknik Informatika (KARMAPATI), 8(2), 319. https://doi.org/10.23887/karmapati.v8i2.18386

Ash-shidiqqi, E. A. (2018). The analysis of character education in Indonesia. International Journal of Humanities, Art and Social Studies (IJHAS), 3(4), 39-46.

Ciğerci, F. M. (2020). Primary school teacher candidates and 21st century skills. International Journal of Progressive Education, 16(2), 157-174. https://doi.org/10.29329/ijpe.2020.241.11

Fitriyani, N. (2019). Pengembangan Media Pembelajaran Audio-Visual Powtoon Tentang Konsep Diri Dalam Bimbingan Kelompok Untuk Peserta Didik Sekolah Dasar. Jurnal Tunas Bangsa, 6(1), 104-114.

Göçen, A., Eral, H. S., \& Bücük, M. H. (2020). Teacher perceptions of a 21st century classroom. International Journal of Contemporary Educational Research, 7(1), 85-98. https://doi.org/10.33200/ijcer.638110

Ilahi, L. R., \& Desyandri. (2018). Pengembangan media pembelajaran tematik terpadu berbasis Powtoon di kelas III sekolah dasar. Journal of Basic Education Studies, 3(2), 1058-1077.

Jan, H. (2017). Teacher of 21 st century: Characteristics and development. IISTE, 7(9), 2225-0484.

Kemendikbud. (2013). Permendikbud Nomor 81A Tahun 2013 tentang Implementasi Kurikulum.

Lestari, N. D., Hermawan, R., \& Heryanto, D. (2018). Pengembangan media pembelajaran menggunakan powtoon untuk pembelajaran tematik sekolah dasar. Jurnal Pendidikan Guru Sekolah Dasar, 3(3), 33-43.

Martens, A. M., \& Gainous, J. (2013). Civic education and democratic capacity: How do teachers teach and what works? Social Science Quarterly, 94(4), 956-976. https://doi.org/10.1111/j.1540-6237.2012.00864.x

Nurdiansyah, E., Faisal, E. El, \& Sulkipani, S. (2018). Pengembangan media pembelajaran berbasis PowToon pada perkuliahan Pendidikan Kewarganegaraan. Jurnal Civics: Media Kajian Kewarganegaraan, 15(1), 1-8. https://doi.org/10.21831/ic.v15i1.16875

Pais, M. H. R., Nogués, F. P., \& Muñoz, B. R. (2017). Incorporating Powtoon as a learning activity into a course on technological innovations as didactic resources for pedagogy programs. International Journal of Emerging Technologies in Learning, 12(6), 120-131. https://doi.org/10.3991/ijet.v12i06.7025

Poggiali, J. (2018). Student responses to an animated character in information literacy instruction. Library $\mathrm{Hi}$ Tech, 36(1), 29-42. https://doi.org/10.1108/LHT-12-2016-0149

Ponza, P. J. R., Jampel, I. N., \& Sudarma, I. K. (2018). Pengembangan media video animasi pada pembelajaran siswa kKelas IV di sekolah dasar. Jurnal Edutech Undiksha, 6(1), 9-19.

Pribadi, B. A. (2016). Desain dan Pengembangan Program Pelatihan Berbasis Kompetensi: Implementasi Model ADDIE. Prenada Media Group.

Puspitarini, Y. D., Akhyar, M., \& Djono, D. (2018). Developing Powtoon-based video learning media for five grade students of elementary school. Advances in Social Science, Education and Humanities Research, 165(Iccsr), 173-177. 
https://doi.org/10.2991/iccsr-18.2018.37

Puspitarini, Y. D., \& Hanif, M. (2019). Using learning media to increase learning motivation in elementary school. Anatolian Journal of Education, 4(2), 53-60. https://doi.org/10.29333/aje.2019.426a

Salim, \& Haidir. (2019). Penelitian Pendidikan: Metode, Pendekatan, dan Jenis. Kencana.

Sari, I. P., \& Syamsi, K. (2015). Pengembangan buku pelajaran tematik-integratif berbasis nilai karakter disiplin dan tanggung jawab di sekolah dasar. Jurnal Prima Edukasia, 3(1), 73-83. https://doi.org/10.21831/ipe.v3i1.4070

Septiani, A. nisa N. S. I., Rejekiningsih, T., Triyanto, \& Rusnaini. (2020). Development of interactive multimedia learning courseware to strengthen students' character. European Journal of Educational Research, 9(3), 1267-1279. https://doi.org/10.12973/eu-jer.9.3.1267

Sugiyono. (2012). Metodelogi Penelitian Kuantitatif Kualitatif dan R\&D. Alfabeta.

Sukiyasa, K., \& Sukoco. (2013). Pengaruh media animasi terhadap hasil belajar dan motivasi belajar siswa materi sistem kelistrikan otomotif. Jurnal Pendidikan Vokasi, 3(1), 126-137. https://doi.org/10.21831/jpv.v3i1.1588

Sukmayadi, V., \& Yahya, A. H. (2020). Indonesian education landscape and the 21st century challenges. Journal of Social Studies Education Research, 11(4), 219234.

Sumardi, L., Rohman, A., \& Wahyudiati, D. (2020). Does the teaching and learning process in primary schools correspond to the characteristics of the 21st century learning? International Journal of Instruction, 13(3), 357-370. https://doi.org/10.29333/iji.2020.13325a

Yatri, I., \& Pratiwi, L. (2017). Peranan media video dalam meningkatkan aktivitas siswa pada pembelajaran IPS di kelas V SDN Mampang Prapatan 02 Pagi. Jurnal Ilmiah Pendidikan Dasar, 4(2), 70-80. https://doi.org/10.30659/pendas.4.2.70-80

Yuliyanto, A., Fadriyah, A., Yeli, K. P., \& Wulandari, H. (2018). Pendekatan Saintifik untuk Mengembangkan Karakter Disiplin dan Tanggung Jawab Siswa Sekolah Dasar. Metodik Didaktik, 13(2). https://doi.org/10.17509/md.v13i2.9307

Conflict of Interest Statement: The authors declare that the research was conducted in the absence of any commercial or financial relationships that could be constructed as a potential conflict of interest. 